\title{
New approaches to the treatment of orphan genetic disorders: Mitigating molecular pathologies using chemicals
}

\author{
RENATA V. VELHO ${ }^{1,2} *$, FERNANDA SPERB-LUDWIG ${ }^{3,4 *}$ and IDA V.D. SCHWARTZ ${ }^{2,3,4,5}$ \\ ${ }^{1}$ Gene Therapy Center, Experimental Research Center, Hospital de Clínicas de Porto Alegre, \\ Rua Ramiro Barcelos, 2350, 90035-903 Porto Alegre, RS, Brasil \\ ${ }^{2}$ Post-Graduation Program on Genetics and Molecular Biology, Universidade Federal do Rio Grande do Sul, \\ Avenida Bento Gonçalves, 9500, Prédio 43323M, Caixa Postal 15053, 91501-970 Porto Alegre, RS, Brasil \\ ${ }^{3}$ Post-Graduation Program in Medical Science, Universidade Federal do Rio Grande do Sul, \\ Rua Ramiro Barcelos, 2400, 90035-903 Porto Alegre, RS, Brasil \\ ${ }^{4}$ BRAIN Laboratory, Experimental Research Center, Hospital de Clínicas de Porto Alegre, \\ Rua Ramiro Barcelos, 2350, 90035-903 Porto Alegre, RS, Brasil \\ ${ }^{5}$ Department of Genetics and Molecular Biology, Universidade Federal do Rio Grande do Sul, \\ Avenida Bento Gonçalves, 9500, Prédio 43433, Sala 207, 91501-970 Porto Alegre, RS, Brasil
}

Manuscript received on December 23, 2014; accepted for publication on March 9, 2015

\begin{abstract}
With the advance and popularization of molecular techniques, the identification of genetic mutations that cause diseases has increased dramatically. Thus, the number of laboratories available to investigate a given disorder and the number of subsequent diagnosis have increased over time. Although it is necessary to identify mutations and provide diagnosis, it is also critical to develop specific therapeutic approaches based on this information. This review aims to highlight recent advances in mutation-targeted therapies with chemicals that mitigate mutational pathology at the molecular level, for disorders that, for the most part, have no effective treatment. Currently, there are several strategies being used to correct different types of mutations, including the following: the identification and characterization of translational readthrough compounds; antisense oligonucleotide-mediated splicing redirection; mismatch repair; and exon skipping. These therapies and other approaches are reviewed in this paper.
\end{abstract}

Key words: antisense oligonucleotide-mediated splicing redirection mutations, exon skipping, mismatch repair, mutation-targeted therapies, translational readthrough.

\section{INTRODUCTION}

Many human diseases have an identified genetic basis. Whereas some of these diseases may be attributed to mutations at multiple loci, a significant number of diseases are believed to be caused by

Correspondence to: Ida Vanessa Doederlein Schwartz

E-mail: ischwartz@hcpa.edu.br

*These authors contributed equally mutations in single genes - monogenic diseases. These monogenic disorders can be subdivided into autosomal dominant, autosomal recessive and X-linked diseases. Although each of these conditions is relatively rare, the many different types of monogenic diseases together affect a substantial portion of the population. The World Health Organization (WHO 2014) estimated the 
global prevalence of all single gene diseases to be approximately 10 in every 1000 births. Some of these diseases can be very severe and even fatal (Wong and Chiu 2010).

Genetic mutations can be classified into four major groups: missense, nonsense, splicing and frameshift. Missense mutations are typically single nucleotide changes that either alter the amino acid in translated proteins (nonsynonymous variations) or do not alter the amino acid (synonymous or 'silent' variations). Nonsense mutations are point mutations in a sequence that create a UAA, UAG, or UGA codon in the coding region of the mRNA, resulting in a premature translation termination and, usually, a nonfunctional or rapidly degraded protein. Splicing mutations result in disruption of critical sequences for splicing, and abolishment of the usual splice sites, or creation of aberrant or cryptic splice sites, which in turn resulting in aberrant proteins. Frameshift mutations most commonly are caused by deletion or insertion of a number of nucleotides that alter the reading frame for any subsequent downstream codons $\mathrm{CHu}$ and Gatti 2008, Orro et al. 2008, Mitui et al. 2009).

The existence of common groups of mutations prompted the hypothesis of common group-specific molecular pathogenesis, e.g., that therapeutic strategies developed against a common mutation group will be effective against similar mutations, regardless of the gene (Hu and Gatti 2008). In this review, we highlight mutation-targeted therapies with chemicals that mitigate mutational pathology at the molecular level (Fig. 1), mainly for recessive disorders for which there is no effective treatment (Table I).

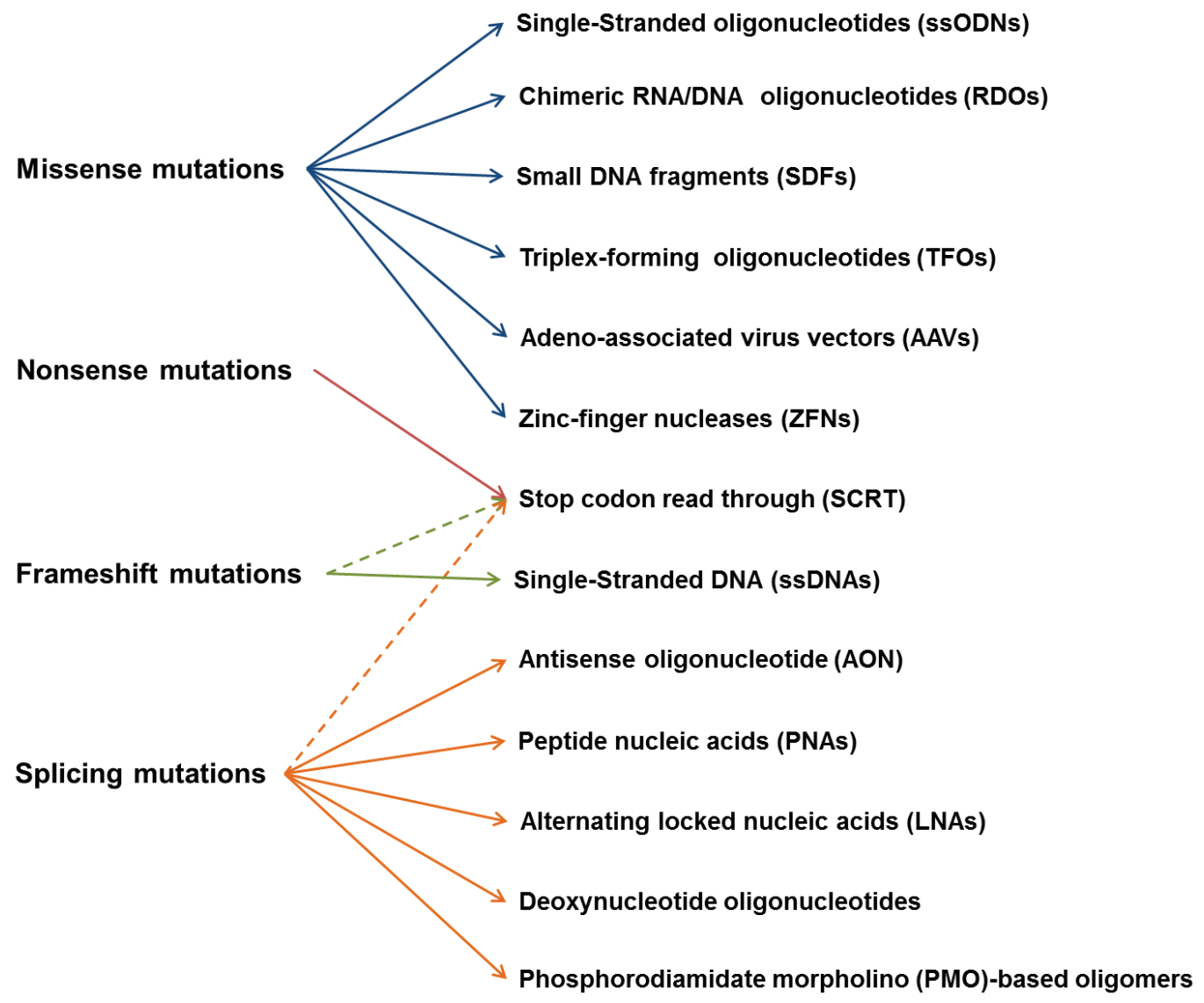

Figure 1 - Mutation-targeted therapies reviewed in this paper. 
TABLE I

Examples of mutation-targeted therapies.

\begin{tabular}{|c|c|c|c|}
\hline Therapy & Target* & Diseases tested & References \\
\hline Aminoglycosides & Stop codon mutations & $\begin{array}{l}\text { cystic fibrosis (CF), Duchene } \\
\text { muscular dystrophy (DMD), } \\
\text { Hurler's syndrome (MPS I), } \\
\text { and diabetes, among others }\end{array}$ & $\begin{array}{l}\text { Diop et al. 2007, Nudelman et al. } \\
\text { 2009, Goldmann et al. } 2010\end{array}$ \\
\hline $\begin{array}{l}\text { Oligonucleotides (peptide } \\
\text { nucleic acids - PNAs; } \\
\text { alternating locked } \\
\text { nucleic acids - LNAs } \\
\text { and; phosphoradiamidate } \\
\text { morpholino-based oligomers } \\
\text { - PMOs) }\end{array}$ & Splicing mutations & $\begin{array}{c}\text { CF, } \beta \text {-thalassemia, } \\
\text { Hutchinson-Gilford progeria } \\
\text { syndrome, DMD and spinal } \\
\text { muscular atrophy }\end{array}$ & $\begin{array}{l}\text { Friedman et al. 1999, Suwanmanee } \\
\text { et al. 2002, Scaffidi and Misteli 2005, } \\
\text { van Deutekom et al. 2007, Kinali et } \\
\text { al. 2009, Cirak et al. 2011, Hua et } \\
\text { al. 2010, Nlend Nlend et al. 2010, } \\
\text { Taylor et al. 1999, Giles et al. } 1999\end{array}$ \\
\hline $\begin{array}{l}\text { Single-stranded } \\
\text { oligonucleotides (ssODNs) }\end{array}$ & Missense mutations & - & $\begin{array}{l}\text { Falgowski et al. 2011, Bertoni et al. } \\
2009\end{array}$ \\
\hline $\begin{array}{l}\text { Chimeric RNA/DNA } \\
\text { oligonucleotides (RDOs) }\end{array}$ & Missense mutations & - & Sargent et al. 2011 \\
\hline $\begin{array}{l}\text { Small DNA fragments } \\
\text { (SDFs) }\end{array}$ & Missense mutations & - & \\
\hline $\begin{array}{l}\text { Triplex-forming } \\
\text { oligonucleotides (TFOs) }\end{array}$ & Missense mutations & - & $\begin{array}{l}\text { Falgowski et al. 2011, Bertoni et al. } \\
2009\end{array}$ \\
\hline $\begin{array}{l}\text { Adeno-associated virus } \\
\text { vectors (AAVs) }\end{array}$ & Missense mutations & $\begin{array}{l}\text { CF, Pompe disease, } \alpha-1 \\
\text { antitrypsin deficiency, } \\
\text { muscular dystrophy, } \\
\text { Batten's disease, Parkinson's } \\
\text { disease, Leber's congenital } \\
\text { amaurosis, hemophilia, } \\
\text { choroideremia, Lipoprotein } \\
\text { Lipase Deficiency }\end{array}$ & $\begin{array}{l}\text { Mittermeyer et al. 2012, Zhong et al. } \\
\text { 2012, Smith et al. 2013, MacLaren } \\
\text { et al. 2014, Mendell et al. 2015, } \\
\text { Mingozzi and High } 2011\end{array}$ \\
\hline Zinc-finger nucleases (ZFNs) & $\begin{array}{c}\text { Missense and } \\
\text { Frameshift mutations }\end{array}$ & $\begin{array}{l}\text { X-linked severe combined } \\
\text { immune deficiency (SCID) }\end{array}$ & $\begin{array}{l}\text { Granja et al. 2014, Aarts and Riele } \\
\text { 2011, Urnov et al. 2005, Rahman et } \\
\text { al. } 2011\end{array}$ \\
\hline $\begin{array}{l}\text { Single-stranded DNA } \\
\text { (ssDNA) }\end{array}$ & Frameshift mutations & - & Morita et al. 2011 \\
\hline $\begin{array}{l}\text { Cell therapy combined with } \\
\text { gene therapy }\end{array}$ & Frameshift mutations & $\beta$-thalassemia & Chang et al. 2006 \\
\hline iPS cells & Frameshift mutations & $\begin{array}{c}\text { sickle cell anemia and } \\
\beta \text {-thalassemia }\end{array}$ & Hanna et al. 2007, Ye et al. 2009 \\
\hline
\end{tabular}

*The therapies are not exclusive to the targets indicated in this table; they could be used for other targets. (-) Not tested.

\section{AMINOGLYCOSIDES AND OTHERS DRUGS THAT PROMOTE STOP CODON READTHROUGH}

Mutations that introduce premature stop codons (PTCs) into the coding sequences of genes have been implicated in numerous inherited diseases and several cancers, and at least 2,400 different genetic disorders have at least one causative nonsense allele (Mort et al. 2008, OMIM 2015).
In general, it has been estimated that nonsense mutations account for $\sim 11 \%$ of all variations that cause inherited disorders and as many as $20 \%$ of the protein-coding region located, single base-pair mutations that cause these diseases (Ryan 2014, HGMD 2015). PTCs can originate from nonsense mutations, frameshift mutations, or from aberrant splicing that generates mRNA isoforms that lead 
to the production of nonfunctional, truncated or deleterious proteins (Linde and Kerem 2008, Kandasamy et al. 2011). Typically, these mutations result in the activation of nonsense mediated RNA decay (NMD), whereby PTC-containing mRNAs are targeted for rapid degradation. This mechanism blocks the production of truncated proteins, which leads to dominant-negative effects on cell function (Silva and Romão 2009, Almeida et al. 2012). Strategies for inducing stop codon readthrough offer the possibility of reducing the pathology caused by this type of mutation. There are at least two different scenarios in which PTC therapies may be maximally effective: (i) diseases in which a much lower than normal level of the deficient protein activity may be therapeutic (e.g., hemophilia and cystic fibrosis - CF); and (ii) diseases in which the therapeutic protein has a very long half-life and thus can accumulate to significant levels via PTC suppression (e.g., Duchene muscular dystrophy DMD) (Hainrichson et al. 2008, Kandasamy et al. 2011).

Aminoglycosides such as gentamicin, amikacin and tobramycin have important clinical applications in the treatment of serious Gram-negative bacterial infections, and in the experimental treatment of recessive diseases with nonsense mutations (Jana and Deb 2006, Hainrichson et al. 2008, Vecsler et al. 2011, Peltz et al. 2013). These molecules bind to the decoding site of the $16 \mathrm{~S}$ or $18 \mathrm{~S}$ ribosomal RNA in prokaryotes and eukaryotes, respectively, inducing a local conformational change ( $\mathrm{Hu}$ and Gatti 2008, Halvey et al. 2012). In prokaryotes, the binding of aminoglycoside is highly specific and is mediated through adenine 1408 in the $16 \mathrm{~S}$ ribosome, thus leading to the inhibition of protein synthesis. However, in eukaryotes, the corresponding nucleotide is a guanine and the binding is less efficient, resulting in translational readthrough by the insertion of an amino acid at the stop codon (Keeling and Bedwell 2002, SánchezAlcudia et al. 2012).

Aminoglycoside antibiotics were the first small-molecule drugs that rendered promising results, and this approach has been validated by numerous in vitro and in vivo experiments in different disorders, including CF, DMD, Hurler's syndrome (MPS I), and diabetes, among others (Diop et al. 2007, Nudelman et al. 2009, Goldmann et al. 2010). With direct clinical relevance, some trials of aminoglycoside therapy have been carried out in humans with PTC mutations. The most promising resulted from topically administered gentamicin in $\mathrm{CF}$ patients. After treatment, nasal potential difference measurements improved considerably in individuals with PTC mutations. Furthermore, full-length CFTR protein was detected in the nasal epithelial cells of two treated individuals (Wilschanski et al. 2003, Clancy et al. 2006, Sermet-Gaudelus et al. 2007). In patients with nonsense mutation-mediated DMD, there was evidence that intravenous gentamicin administration suppressed nonsense mutations, as determined by the analysis of full-length dystrophin in muscle biopsies (Politano et al. 2003). These experiments demonstrated the ability of selected aminoglycoside structures to induce mammalian ribosomes to read through disease-causing PTCs (Fig. 2) and partially restore full-size functional proteins (Burke and Mogg 1985, Kandasamy et al. 2011, Sánchez-Alcudia et al. 2012).

However, readthrough efficiency depends on the PTC (UGA > UAG > UAA); on the nucleotide context of the mutation, particularly the nucleotide immediately after the stop codon $(\mathrm{C}>\mathrm{U}>\mathrm{A} \geq$ $\mathrm{G})$; and on other factors involved in readthrough regulation (Bidou et al. 2004, Kimura et al. 2005, Diop et al. 2007). In addition, the efficiency of aminoglycoside therapy depends on the molecular mechanism by which the nonsense mutation cause the defects and on the level of active protein required to reduce clinical symptoms. Moreover, results are impaired by the need for regular intravenous administration and the toxic side effects (nephrotoxicity and ototoxicity) of long-term treatment (Finkel 2010). With the aim of identifying alternative compounds that do not elicit toxic side effects, several studies have been 
a

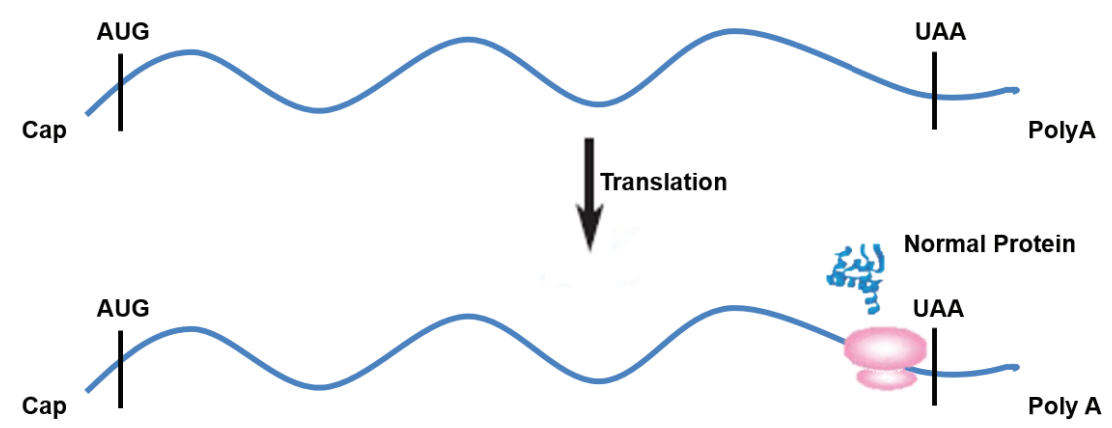

b

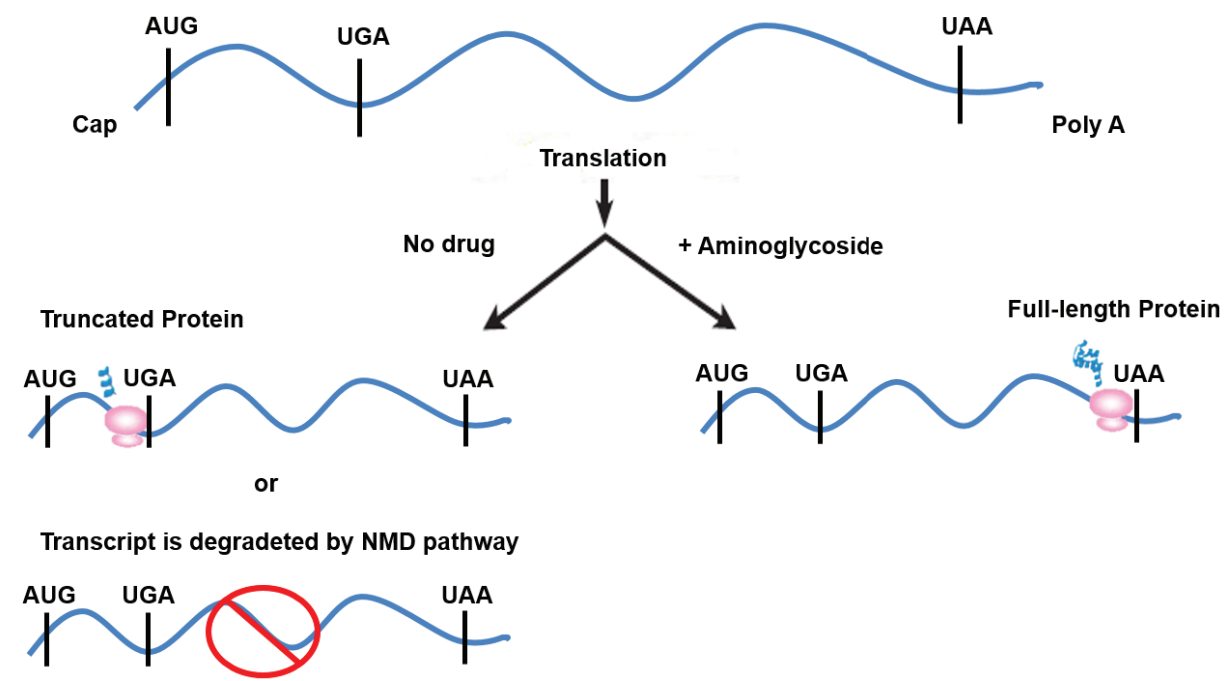

Figure 2 - Schematic diagram of gene regulation and readthrough strategy. The relative positions of caps, polyadenylation sequences, and initiation and termination codons within mRNAs are shown. (a) In wild type cells, normal mRNAs encode complete proteins. (b) In mutant cells, the mRNAs contain a premature stop codon, and truncated proteins are translated in the absence of aminoglycoside or the transcript is degraded by the NMD pathway. The presence of aminoglycoside allows the incorporation of a random amino acid at the terminal stop codon of the mutant mRNA. Full-length proteins result from the aminoglycoside-induced readthrough.

successfully carried out using high throughput screens or designed aminoglycosides (Hainrichson et al. 2008, Du et al. 2009, Kandasamy et al. 2011, Vecsler et al. 2011, Peltz et al. 2013, Karijolich and Yu 2014, Keeling et al. 2014).

The recently identified compound PTC124, or ataluren, is a non-aminoglycoside, readthroughinducing compound that shows potent PTC suppression while preserving the natural termination codon. Further more, it offers the advantages of having no obvious toxic effects and is orally bioavailable (Welch et al. 2007, Peltz et al. 2013, Ryan 2014). This drug has shown promising results for DMD, other dystrophinopathies, CF, MPS I, and Carnitine Palmitoyltransferase 1A Deficiency (CPT1A), with the potential of treating a wider range of genetic disorders (Finkel 2010, Sermet-Gaudelus et al. 2010, Rowe et al. 2012, Peltz et al. 2013, Ryan 2014).

A set of clinical studies have been conducted with ataluren in CF and DMD. A phase IIb international, randomized, double blind, placebocontrolled study evaluated the effects of ataluren therapy on ambulatory ability in 174 patients ( $\geq 5$ years of age) with DMD for 48 weeks (Finkel et al. 2010, 2013, McDonald et al. 2013a, b). Patients 
were stratified based on their age $(<9$ versus $\geq 9$ years), use of corticosteroids (yes versus no), and baseline 6 -min walk distance (6MWD) $(<350$ or $\geq 350 \mathrm{~m}$ ) and were randomized 1:1:1 to placebo, ataluren low dose, or ataluren high dose with all regimens given three times per day. This study showed that ataluren $10,10,20 \mathrm{mg} / \mathrm{kg}$ was more effective than placebo, increasing the mean 6MWD by $31.3 \mathrm{~m}$ over the 48 -week period and representing a $48 \%$ reduction in the risk of the 6 MWD worsening by $10 \%$. Timed function tests of muscle function (walking/ running $10 \mathrm{~m}$, up and down stairs) also revealed positive trends for ataluren 10, 10, 20 $\mathrm{mg} / \mathrm{kg}$, as evidenced by less decline over the 48 weeks. Ataluren showed activity and safety in this short-term study, supporting the further evaluation of ataluren 10,10,20 mg/kg and 20,20,40 mg/ $\mathrm{kg}$ in similar future studies (Finkel et al. 2013, McDonald et al. 2013a, b).

In CF patients $\geq 6$ years of age, a phase III 48week, double-blind study was performed to assess the safety and efficacy of ataluren (Clancy et al. 2006, Rowe et al. 2012, Kerem et al. 2014). Patients were stratified by age, chronic inhaled antibiotic use and percent-predicted forced expiratory volume in $1 \mathrm{~s}$ (FEV1). At Week 48, the difference in the mean relative change from baseline in percentpredicted FEV1 between ataluren and placebo was $3.0 \%$, and the mean pulmonary exacerbation rate was 23\% lower for ataluren (Peltz et al. 2013, Kerem et al. 2014). These results were more important in patients who did not chronically take inhaled antibiotics. In this study, several inhaled antibiotics were used chronically by patients, including colistin, aztreonam and tobramycin. However, analysis of the effects of these different inhaled antibiotics on percent-predicted FEV1 and pulmonary exacerbation rates indicated that tobramycin antagonized the effect of ataluren, a finding which was confirmed by in vitro assays. The safety profiles were similar for ataluren and placebo (Rowe et al. 2012, Peltz et al. 2013, Kerem et al. 2014).
PTC124/ataluren (Translarna ${ }^{\mathrm{TM}}-$ PTC Therapeutics, Inc.) is a small molecule, orally available compound (Finkel et al. 2013, Ryan 2014), which is the first drug developed specifically to treat diseases caused by nonsense mutations. Notably, a conditional first approval for the use in European of this drug was achieved for DMD in 2014 (Ryan 2014, EMA 2015).

\section{USE OF THERAPEUTIC OLIGONUCLEOTIDES IN SPLICING MUTATIONS}

RNA mis-splicing diseases account for up to $15 \%$ of all inherited diseases, ranging from neurological to myogenic to metabolic disorders. With the great increase in the performance of genomic sequencing for individual patients, the number of known mutations that affect splicing has risen to $50-60 \%$ of all disease-causing mutations (Wang and Cooper 2007, Baralle et al. 2009, Hammond and Wood 2011). Thus, correction or redirection of pre-mRNA splicing in a mutation-specific context represents a potential gene therapy modality with applicability to many inherited disorders.

Splicing mutations can be grouped into a minimum of five types. Type I is the classical splicing mutation that results in the deletion of an entire exon. Types II, III, and IV are nonclassical splicing mutations that result in pseudoexon inclusion or partial exon deletion. Type $\mathrm{V}$ involves the branch point; although such mutations exist, they have not been targeted for therapy (Hu and Gatti 2008). Exon inclusion, exon exclusion and exon skipping to restore the open reading frame and cryptic splicing are techniques used to correct frameshift mutations (Spitali and Aartsma-Rus 2012).

Antisense oligonucleotide (AON) therapies have been used to correct pre-mRNA splicing in many disease models. Modified oligonucleotides can alter the pathogenic splice signals that are activated by mutations, resulting in close to normal levels of mRNAs that encode functional protein; however, the therapeutic principles for each AON varies considerably (Fig. 3 - Wilton and Fletcher 2011). 
The chemicals that are used to work in animal models include peptide nucleic acids (PNAs), alternating locked nucleic acids (LNAs) and deoxynucleotide oligonucleotides, fully modified (non-gapmer) 2'-substituted oligonucleotides and phosphorodiamidate morpholino (PMO)-based

(a) Exon exclusion
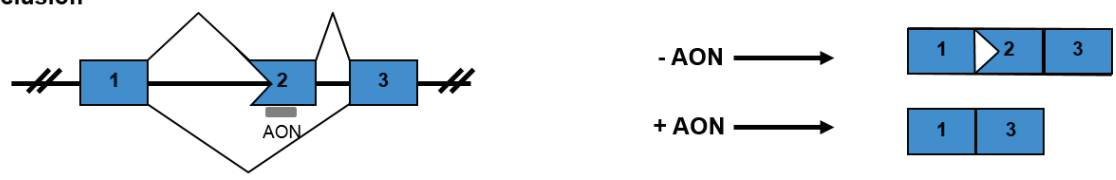

(b) Exon inclusion
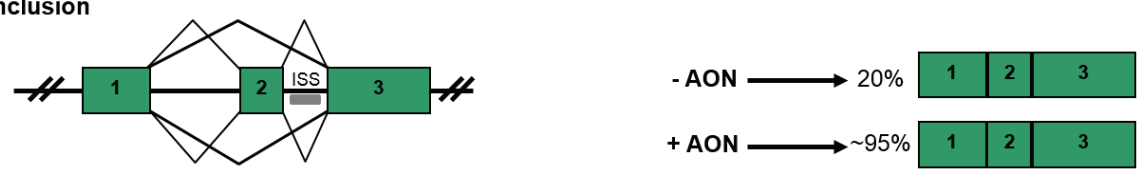

(c) Cryptic splice sites
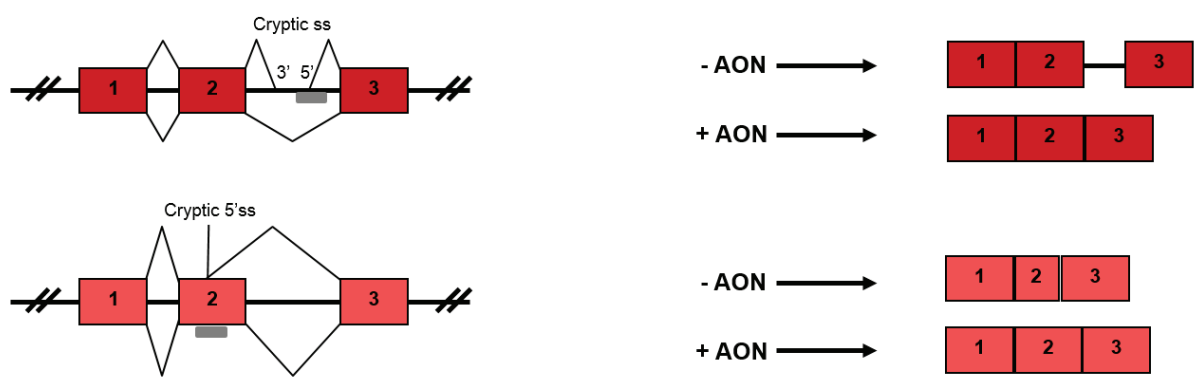

(d) Pseudoexon
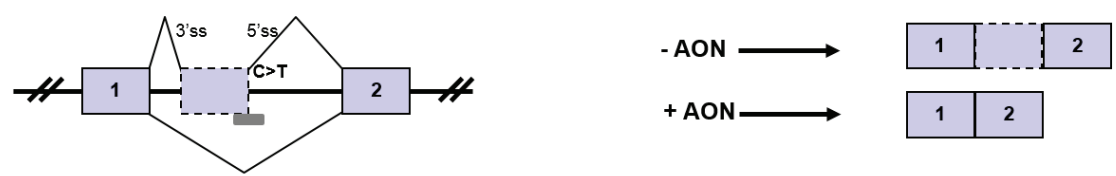

Figure 3 - Antisense oligonucleotides (AONs) therapies are used to correct pre-mRNA splicing. (a) Exon exclusion: Large-scale deletions can result in out-of-frame mRNA transcripts. AONs directed toward an exon splice enhancer element within the mutated exon result in exclusion of the exon and, thus, an alternative in-frame transcript. (b) Exon inclusion: A mRNA transcript can lose one exon owing to negative splicing regulatory elements within and surrounding this exon and produce a less functional protein. Treatment with AON directed toward an intron splice silencer (ISS) can increase the inclusion of the exon from $20 \%$ to approximately $95 \%$, as seen in the SMN2 gene (Hua et al. 2010). (c) Cryptic splice sites: This can result in inclusion of introns or partial deletions of exons from mRNA. The hypothetical intronic mutation illustrated creates an intronic 5' splice site (ss) and activates a cryptic 3' ss within intron 2. AONs targeting the mutated intron 5' ss blocks recognition by the splicing machinery and generates transcripts without the aberrant intron element. Similarly, a mutation within exon 2 creates a cryptic 5 ' ss preferentially utilized over the natural splice site. AONs directed to the mutant cryptic site cause steric blockage of the splicing machinery and redirect splicing to the natural 5' ss. (d) Pseudoexon: A C-A mutation within intron 1 strengthened the 50ss of a pseudoexon (dashed box), which maintains a strong 3' ss. AONs directed to the pseudoexon 5' ss and inclusion of C-A mutation restored the natural transcript (Adapted from Hammond and Wood 2011). 
oligomers (Kole et al. 2012). By sterically blocking mutations and regulatory sequences within the pre-mRNA transcript, AONs have been used to induce the skipping or inclusion of exons, to block pseudoexons from recognition and to influence the alternative splicing of pathogenic isoforms (Hammond and Wood 2011).

Antisense oligonucleotides have been used to successfully modulate RNA splicing in CF (CFTR gene)(Friedmanetal. 1999), $\beta$-thalassemia $(\beta$-globin gene) (Suwanmanee et al. 2002), HutchinsonGilford progeria syndrome (LMNA gene) (Scaffidi and Misteli 2005) and DMD (Dystrophin gene) (van Deutekom et al. 2007, Kinali et al. 2009, Cirak et al. 2011). These compounds have also been used to modify alternative splicing in the SMN2 (spinal muscular atrophy) (Hua et al. 2010, Nlend Nlend et al. 2010), Bcl-x (Taylor et al. 1999), and C-myc genes (Giles et al. 1999), suggesting that such antisense oligonucleotides are capable of crossing the blood-brain barrier in amounts sufficient to restore neural activity.

The data from the first clinical trial in DMD patients were highly encouraging, and technical advances in the development of methods for both directed exon exclusion and directed exon inclusion suggest that such antisense oligonucleotide splicecorrection therapies may have broad application (Wood et al. 2010, Dick et al. 2013, Anthony et al. 2014).

\section{MISSENSE MUTATIONS}

Targeted gene alteration is a promising method for correcting single-base mutations. In this technique, endogenous DNA repair pathways of the cell are activated, leading to specific genetic correction of single-base mutations in the genome. This strategy can be implemented using single-stranded oligonucleotides (ssODNs), chimeric RNA/DNA oligonucleotides (RDOs), small DNA fragments (SDFs), triplex-forming oligonucleotides (TFOs), adeno-associated virus vectors (AAVs) and zincfinger nucleases (ZFNs) (Jensen et al. 2011).
Gene editing using ssODNs can alter single nucleotides and induce stable alterations at the genomic level. Several studies have tested technique optimizations. ssODNs are oligonucleotides that are $<200 \mathrm{bp}$ in length and are designed to anneal to the lagging strand to generate a 100 -fold greater 'editing' efficiency than those that anneal to the leading strand. The majority of editing events ( $70 \%$ ) occur by the incorporation of the ssODN within the lagging strand during replication (Falgowski et al. 2011). Bertoni et al. (2009) showed that ssODNs that contain a methyl-CpG modification and are capable of binding to the methyl- $\mathrm{CpG}$ binding domain protein 4 (MBD4) are able to induce $>10$-fold higher levels of gene correction than ssODNs lacking these specific modifications.

RDOs are a class of oligonucleotides used for gene targeting with a correction efficiency of approximately $50 \%$; however, the reproducibility of these studies has been limited in mammalian systems (Sargent et al. 2011). TFOs are ssODNs that are typically $10-40 \mathrm{nt}$ in length and bind to specific regions in duplex DNA as a third strand to form a triple helix. TFOs act in polypurine or polypyrimidine regions of DNA and bind DNA via Hoogsteen hydrogen bonds (Sargent et al. 2011, Pauwels et al. 2014).

Gene therapy remains a great promise for the treatment of genetic diseases. Recombinant AAV have been successfully used to transduce a variety of genes in different cellular types in vitro and have been validated in small and large animal models (in vivo). There are three critical elements in gene transfer: the gene, the target tissue and the vector. The gene is the active therapeutic agent, but the virus-derived vector is the determinant of the therapeutic success and of the toxicity profile (Potter et al. 2014). AAV vectors are currently being used in Phase I/II clinical trials for many diseases, such as $\mathrm{CF}$, Pompe disease, $\alpha-1$ antitrypsin deficiency, muscular dystrophy, Batten's disease, Parkinson's disease, Leber's congenital amaurosis, hemophilia, and choroideremia (Mittermeyer et al. 2012, Zhong 
et al. 2012, Smith et al. 2013, MacLaren et al. 2014, Mendell et al. 2015). Furthermore, this treatment is already licensed in Europe for lipoprotein lipase deficiency (Mingozzi and High 2011).

More recently, the use of ZFNs has become a powerful strategy. These nucleases are engineered to introduce site-specific double-stranded DNA breaks in the genome. Site-specific alterations of the genome are then accompanied by homologydirected repair of the double-stranded DNA breaks using a linear double-stranded donor DNA fragment carrying the desired alteration. This strategy has been shown to be highly efficient at disrupting genes in several cell types and model organisms, making it a good choice for novel therapeutic applications (Granja et al. 2014). Although this approach can be remarkably effective, one obstacle of this approach is that ZFNs need to be designed and constructed for every specific location to be modified. Thus, ZFNs are most useful for repairing frequently occurring mutations (Aarts and Riele 2011).

A new approach that combines ZFNs with AAV has been studied. Based on the enzyme's ability to create a site-specific DNA double-strand break, Händel et al. (2012) demonstrated that ZFNencoding AAV expression vectors can be employed to induce large chromosomal deletions or to disrupt genes.

Current strategies combine different techniques for sequence-selective double-strand DNA targeting, including TFOs, synthetic hairpin polyamides, engineered zinc finger proteins and peptide nucleic acids. TFOs bind as a third strand in the major groove of dsDNA. In the classical 'pyrimidine motif', thymine/cytosine containing TFOs hybridize to the complementary adenine/ guanine bases of the target in a parallel orientation via Hoogsteen base pairing (Hansen et al. 2009).

Many of these strategies reviewed here are commonly used for missense, nonsense and frameshift mutations.

\section{FRAMESHIFT MUTATIONS}

Frameshift mutations change the reading frame, thus inducing a completely different translation from the original one. These mutations often inactivate genes by producing truncated, nonfunctional proteins (Morita et al. 2011).

The use of oligonucleotides in targeted sequence conversion has been developed for introducing sequence alterations, including deletions, insertions, and base-substitutions, into genomic DNA (de Semir and Aran 2006, Parekh-Olmedo and Kmiec 2007). Studies have demonstrated that both single-stranded DNA (ssDNA) fragments containing the sense sequence and the tailed duplex (TD) DNA fragments, prepared by annealing an oligonucleotide to the ssDNA fragment, have the ability to correct singlebase substitution mutations. However, the ssDNA fragments correct mutations with low efficiency. Because the correction efficiencies of single-base substitution mutations by the TD fragments are higher, it is important to consider and examine the ability of the TD fragments to correct frameshift mutations (Morita et al. 2011).

Another approach for frameshift mutations therapy is the use of engineered zinc-finger proteins to recognize a unique chromosomal site, which can be fused to a nuclease domain. Moreover, double-strand breaks induced by the resulting ZFN can create specific sequence alterations by stimulating homologous recombination between the chromosome and an extrachromosomal DNA donor (Urnov et al. 2005, Rahman et al. 2011). Urnov et al. (2005) showed that ZFNs designed against an X-linked severe combined immune deficiency (SCID) mutation in the $I L 2 R \gamma$ gene yielded higher than $18 \%$ of the gene-modified human cells, even without selection.

The targeted gene correction technique employs a site-specific DNA lesion to promote a homologous recombination that eliminates the mutation in a gene of interest. However, doublestrand breaks that are typically used to initiate 
corrections can also result in genomic instability if deleterious repair occurs rather than gene correction, possibly compromising the safety of the targeted gene correction (Davis and Maizels 2011).

Cell therapy combined with gene therapy is a broadly expanding field in the correction of frameshift mutations and other mutations. Using a transgenic/knockout sickle cell anemia mouse model containing the human $\beta^{\mathrm{S}}$-globin gene, Chang et al. (2006) prepared embryonic stem (ES) cells from blastocysts that had the sickle cell anemia genotype and carried out homologous recombination with DNA constructs containing the $\beta^{\mathrm{A}}$-globin gene. Hematopoietic cells differentiated from these ES cells, produced both hemoglobin A and hemoglobin $\mathrm{S}$, having the potential to correct the sickle and $\beta$-thalassemia mutations.

The development of induced pluripotent stem (iPS) cells allowed stem cell therapies to advance to new frontiers. Using a humanized sickle cell anemia mouse model, Hanna et al. (2007) showed that mice can be rescued after transplantation with hematopoietic progenitors obtained in vitro from autologous iPS cells. This was achieved after correcting the human sickle hemoglobin allele with gene-specific targeting. Ye et al. (2009) treated fibroblasts from patients with $\beta$-thalassemia caused by frameshift mutations. They showed that iPS cells could be produced from the somatic cells of these patients and that the mutations could be corrected with gene targeting. Cells differentiated into hematopoietic cells can be returned to the patient. The innovation of reprogramming somatic cells into induced pluripotent stem cells provides many possible new approaches for treating $\beta$-thalassemia and other genetic diseases.

Nature provides an interesting model of mutation reversion that should be thoroughly explored. Revertant mosaicism is a naturally occurring phenomenon that involves the spontaneous correction of a pathogenic mutation in a somatic cell. Recent studies suggest that this is not a rare event and that reversion could be clinically relevant to phenotypic expression and patient treatment. Indeed, revertant cell therapy represents a potential 'natural gene therapy' because in vivo reversion obviates the need for further genetic correction. Revertant mosaicism has been observed in several inherited conditions, including epidermolysis bullosa, a heterogeneous group of blistering skin disorders (Lai-Cheong et al. 2011).

Several structural modifications and techniques are being developed to optimize the therapeutic responses to these new treatments. However, it is also apparent that much remains to be learned regarding the organization of these modifications. Eventually, principles with predictive value should emerge to guide the use of these new approaches.

\section{CONCLUSIONS}

Translational research for rare diseases is clearly a resource-intensive undertaking in terms of cost and time. Therefore, the central aspects of any broadly successful approach for this class of diseases will be to create and employ generalizable methodologies whenever possible. The identification of novel, non-toxic and efficient therapeutic agents and advances in the stability and delivery of antisense oligonucleotide splice-correction therapies are necessary. Although the approaches reviewed in this paper are credible and feasible, the prospect of a rapid configuration of numerous effective disease therapies should be viewed in perspective. Among the many genetic disorders that have been or will shortly be molecularly characterized, only a small number will be tractable with the approaches reviewed here; however, the generation of information will at least help to move a larger number of disorders closer to the day of effective therapy.

\section{ACKNOWLEDGMENTS}

We thank the funding agencies who supported this study: Fundo de Incentivos à Pesquisa e Eventos do Hospital de Clínicas de Porto Alegre (FIPE - HCPA), Fundação de Amparo à Pesquisa do 
Estado do Rio Grande do Sul (FAPERGS) and Conselho Nacional de Desenvolvimento Científico e Tecnológico (CNPq, Brazil).

\section{RESUMO}

Com o avanço e a popularização de técnicas moleculares, a identificação de mutações genéticas que causam doenças aumentou drasticamente. Deste modo, o número de laboratórios disponíveis para investigar uma determinada doença e, consequentemente, o número de diagnósticos, aumentou ao longo do tempo. Embora seja necessário identificar mutações e fornecer diagnósticos, é crucial também desenvolver abordagens terapêuticas específicas baseadas nestas informações. Esta revisão tem como objetivo destacar os avanços recentes em terapias mutação-alvo com produtos químicos que mitiguem a patologia mutacional ao nível molecular, para doenças que, para a maior parte, não têm tratamento eficaz. Atualmente, existem várias estratégias sendo utilizadas para corrigir diferentes tipos de mutações, incluindo as seguintes: a identificação e caracterização de compostos readthrough traducionais; redirecionamento de splicing mediado por oligonucleotídeos de sentido contrário; reparo por mismatch; e salto de exon. Estas terapias e outras abordagens são revistas neste artigo.

Palavras-chave: redirecionamento antisense de splicing mediado por oligonucleotídeo, remoção de exon, reparo por mismatch, terapias alvo-molecular, readthrough traducional.

\section{REFERENCES}

Aarts M AND Riele HT. 2011. Progress and prospects: oligonucleotide-directed gene modification in mouse embryonic stem cells: a route to therapeutic application. Gene Ther 18: 213-219.

Almeida ACG, Pasqualim G, Mayer FQ, Schwartz IVD, Souza CF, Giugliani R AND Matte U. 2012. Analysis of cDNA molecules is not suitable for the molecular diagnosis of Mucopolysaccharidosis type I. Diagn Mol Pathol 21: 53-55.

ANTHONY K ET AL. 2014. Biochemical characterization of patients with in-frame or out-of-frame DMD deletions pertinent to exon 44 or 45 skipping. JAMA Neurol 71: $32-40$.

Baralle D, Lucassen A and Buratti E. 2009. Missed threads. The impact of pre-mRNA splicing defects on clinical practice. EMBO Rep 10: 810-816.
BERTONI C, RUSTAGI A AND RANDO TA. 2009. Enhanced gene repair mediated by methyl-CpG-modified single-stranded oligonucleotides. Nucleic Acids Res 37: 7468-7482.

Bidou L, Hatin I, Perez N, Allamand V, Panthier JJ AND RoussET JP. 2004. Premature stop codons involved in muscular dystrophies show a broad spectrum of readthrough efficiencies in response to gentamicin treatment. Gene Ther 11: 619-627.

Burke JF AND MoGg AE. 1985. Suppression of a nonsense mutation in mammalian cells in vivo by the aminoglycoside anthiotics G-418 and paromomycin. Nucleic Acids Res 13: 6265-6272.

Chang JC, Ye L AND KAN YW. 2006. Correction of the sickle cell mutation in embryonic stem cells. Proc Natl Acad Sci USA 103: 1036-1040.

CIRAK S ET AL. 2011. Exon skipping and dystrophin restoration in patients with Duchenne muscular dystrophy after systemic phosphorodiamidate morpholino oligomer treatment: an open-label, phase 2, dose-escalation study. Lancet 378: 595-605.

Clancy JP, Konstan MW, Rowe S, ACCurso F, Zeitlin P, Moss R, BeboK Z, NorthCUTt VJ, ElFring GL AND MiLLER L. 2006. A phase II study of PTC124 in CF patients harboring premature stop mutations. Ped Pulmonol Suppl 41: 269.

DAVIS L AND MAIZELS N. 2011. DNA nicks promote efficient and safe targeted gene correction. PLoS One 6: e23981.

De SEMIR D AND Aran J. 2006. Targeted Gene Repair: The Ups and Downs of a Promising Gene Therapy Approach. Curr Gene Ther 6: 481-504.

Dick E, KALRA S, ANDERSON D, GEORGE V, Ritso M, LAVAL SH, BARRESI R, AARTSMA-RUS A, LOCHMÜLLER H AND DENNING C. 2013. Exon skipping and gene transfer restore dystrophin expression in human induced pluripotent stem cells-cardiomyocytes harboring DMD mutations. Stem Cells Dev 22: 2714-2724.

Diop D, Chauvin C AND JEAN-JEAN O. 2007. Aminoglycosides and other factors promoting stop codon readthrough in human cells. C R Biol 330: 71-79.

Du L ET AL. 2009. Nonaminoglycoside compounds induce readthrough of nonsense mutations. J Exp Med 206: 22852297.

EMA - The European Medicines Agency. 2015. Translarn $^{\mathrm{TM}}$. Available in: http://www.ema.europa.eu/. Accessed at January, 10, 2015.

FALGOWski K, FALGOwsKi C, York-Vickers C AND KMIEC EB. 2011. Strand bias influences the mechanism of gene editing directed by single-stranded DNA oligonucleotides. Nucleic Acids Res 39: 4783-4794.

Finkel R, Wong B, Bushby K, Reha A, Elfring GL, Miller LL, Babiak J, Morsy MA, Peltz S AND Welch E. 2010. Results of a Phase 2b, dose-ranging study of ataluren (PTC124®) in nonsense mutation Duchenne/ 
Becker muscular dystrophy (nmDBMD). Neuromuscul Disord 20: 656-657.

FINKEL RS. 2010. Read-through strategies for suppression of nonsense mutations in Duchenne/ Becker muscular dystrophy: aminoglycosides and ataluren (PTC124). J Child Neurol 25: 1158-1164.

FINKEL RS ET AL. 2013. Phase 2a study of ataluren-mediated dystrophin production in patients with nonsense mutation Duchenne muscular dystrophy. PLoS One 8: e81302.

Friedman KJ, Kole J, COHN JA, KNOWLes MR, Silverman LM AND KolE R. 1999. Correction of Aberrant Splicing of the Cystic Fibrosis Transmembrane Conductance Regulator (CFTR) Gene by Antisense Oligonucleotides. J Biol Chem 274: 36193-36199.

Giles RV, Spiller DG, Clark RE AND TidD DM. 1999. Antisense Morpholino Oligonucleotide Analog Induces Missplicing of C- myc mRNA. Antisense Nucleic Acid Drug Dev 9: 213-220.

GOLDMANN T, REBIBO-SABBAH A, OVERLACK N, NUDELMAN I, BELAKHOV V, BAASOV T, BEN-YOSEF T, WOLFRUM U AND NAGEL-Wolfrum K. 2010. Beneficial readthrough of a USH1C nonsense mutation by designed aminoglycoside NB30 in the retina. Invest Ophthalmol Vis Sci 51: 6671-6680.

GRANJA S, MARChiQ I, BALTAZAR F AND POUYSSÉGUR J. 2014. Gene disruption using zinc finger nuclease technology. Methods Mol Biol 1165: 253-260.

HAINRICHSON M, NUDELMAN I AND BAASOV T. 2008. Designer aminoglycosides: the race to develop improved antibiotics and compounds for the treatment of human genetic diseases. Org Biomol Chem 6: 227-239.

Halvey PJ, Liebler DC AND Slebos RJC. 2012. A reporter system for translational readthrough of stop codons in human cells. FEBS Open Bio 2: 56-59.

HAMMOND SM AND WoOD MJ. 2011. Genetic therapies for RNA mis-splicing diseases. Trends Genet 27: 196-205.

HÄndel EM, Gellhaus K, Khan K, Bednarski C, Cornu TI, MÜller-Lerch F, Kotin RM, Heilbronn R AND CATHomen T. 2012. Versatile and efficient genome editing in human cells by combining zinc-finger nucleases with adeno-associated viral vectors. Hum Gene Ther 23: 321329.

HANNA J ET AL. 2007. Treatment of sickle cell anemia mouse model with iPS cells generated from autologous skin. Science 318: 1920-1923.

HANSEN ME, BENTIN T AND NIELSEN PE. 2009. High-affinity triplex targeting of double stranded DNA using chemically modified peptide nucleic acid oligomers. Nucleic Acids Res 37: 4498-4507.

HGMD - The Human Gene Mutation Database. 2015. Available in: http://www.hgmd.cf.ac.uk. Accessed at February, 24, 2015.
HU H AND GATTI RA. 2008. New approaches to treatment of primary immunodeficiencies: fixing mutations with chemicals. Curr Opin Allergy Clin Immunol 8: 540-546.

Hua Y, SAHAshi K, Hung G, Rigo F, PAssini MA, Bennett CF AND KRAINER AR. 2010. Antisense correction of SMN2 splicing in the CNS rescues necrosis in a type III SMA mouse model. Genes Dev 24: 1634-1644.

JANA S AND DEB JK. 2006. Molecular understanding of aminoglycoside action and resistance. Appl Microbiol Biotechnol 70: 140-150.

JENSEN NM, DALSGAARD T, JAKOBSEN M, NIELSEN RR, Sørensen CB, Bolund L AND Jensen TG. 2011. An update on targeted gene repair in mammalian cells: methods and mechanisms. J Biomed Sci 18: 10.

KANDASAMY J, ATIA-GLikin D, BELAKHOV V AND BAASOV T. 2011. Repairing faulty genes by aminoglycosides: Identification of new pharmacophore with enhanced suppression of disease-causing nonsense mutations. Medchemcomm 2: 165.

KARIJOLICH J AND YU YT. 2014. Therapeutic suppression of premature termination codons: mechanisms and clinical considerations (review). Int J Mol Med 34: 355-362.

KeELING KM AND BeDwell DM. 2002. Clinically relevant aminoglycosides can suppress disease-associated premature stop mutations in the Idua and P53 cDNAs in a mammalian translation system. J Mol Med (Berl) 80: 367-376.

Keeling KM, Xue X, Gunn G And Bedwell DM. 2014. Therapeutics based on stop codon readthrough. Annu Rev Genomics Hum Genet 15: 371-394.

KEREM E ET AL. 2014. Ataluren for the treatment of nonsensemutation cystic fibrosis: a randomised, double-blind, placebo-controlled phase 3 trial. Lancet Respir Med 2: 539-547.

KIMURA S ET AL. 2005. A novel approach to identify Duchenne muscular dystrophy patients for aminoglycoside antibiotics therapy. Brain Dev 27: 400-405.

KinALI M ET AL. 2009. Local restoration of dystrophin expression with the morpholino oligomer AVI-4658 in Duchenne muscular dystrophy: a single-blind, placebocontrolled, dose-escalation, proof-of-concept study. Lancet Neurol 8: 918-928.

KOLER, KRAINER AR AND ALTMAN S. 2012. RNA therapeutics: beyond RNA interference and antisense oligonucleotides. Nat Rev Drug Discov 11: 125-140.

LAI-CheOng JE, MCGRATH JA And UitTo J. 2011. Revertant mosaicism in skin: natural gene therapy. Trends Mol Med 17: 140-148.

LINDE L AND KEREM B. 2008. Introducing sense into nonsense in treatments of human genetic diseases. Trends Genet 24: 552-563.

MACLAREN RE ET AL. 2014. Retinal gene therapy in patients with choroideremia: initial findings from a phase $1 / 2$ clinical trial. Lancet 383: 1129-1137. 
MCDONALD CM ET AL. 2013a. The 6-minute walk test and other clinical endpoints in duchenne muscular dystrophy: reliability, concurrent validity, and minimal clinically important differences from a multicenter study. Muscle Nerve 48: 357-368

MCDONALD CM ET AL. 2013b. The 6-minute walk test and other endpoints in Duchenne muscular dystrophy: longitudinal natural history observations over 48 weeks from a multicenter study. Muscle Nerve 48: 343-356.

MENDELL JR ET AL. 2015. A phase 1/2a follistatin gene therapy trial for becker muscular dystrophy. Mol Ther 23: 192-201.

MingOzZI F AND HIGH KA. 2011. Therapeutic in vivo gene transfer for genetic disease using AAV: progress and challenges. Nat Rev Genet 12: 341-355.

MitTermeyer G, Christine CW, Rosenbluth KH, BAKer SL, Starr P, Larson P, Kaplan PL, Forsayeth J, AminofF MJ AND BANKIEWICZ KS. 2012. Long-term evaluation of a phase 1 study of AADC gene therapy for Parkinson's disease. Hum Gene Ther 23: 377-381.

Mitui Met AL. 2009. Functional and computational assessment of missense variants in the ataxia-telangiectasia mutated (ATM) gene: mutations with increased cancer risk. Hum Mutat 30: 12-21.

Morita Y, TSuchiYa H, Harashima H AND KamiYA H. 2011. Correction of Frameshift Mutations with Tailed Duplex DNAs. Biol Pharm Bull 34: 1465-1468.

Mort M, IVAnov D, CoOper DN AND Chuzhanova NA. 2008. A meta-analysis of nonsense mutations causing human genetic disease. Hum Mutat 29: 1037-1047.

NLEND NLEND R, MEYer K AND SCHUMPERLi D. 2010. Repair of pre-mRNA splicing: Prospects for a therapy for spinal muscular atrophy. RNA Biol 7: 430-440.

Nudelman I, Rebibo-SabBah A, Cherniavsky M, BELAKHOV V, HAINRICHSON M, CHEN F, SCHACHT J, PILCH DS, Ben-Yosef T AND BAAsOV T. 2009. Development of novel aminoglycoside (NB54) with reduced toxicity and enhanced suppression of disease-causing premature stop mutations. J Med Chem 52: 2836-2845.

OMIM - OnLine Mendelian Inheritance in MAN. 2015. Available in: www.ncbi.nlm.nih.gov. Accessed at February, 24, 2015.

Orro A, Guffanti G, SAlvi E, Macciardi F And Milanesi L. 2008. SNPLims: a data management system for genome wide association studies. BMC Bioinformatics 9(Suppl 2): S13.

PareKh-Olmedo H And KMiec EB. 2007. Progress and prospects: targeted gene alteration (TGA). Gene Ther 14: 1675-1680.

Pauwels K, Podevin N, Breyer D, CARroll D AND Herman P. 2014. Engineering nucleases for gene targeting: safety and regulatory considerations. N Biotechnol 31: 18-27.

Peltz SW, Morsy M, Welch EM AND JacobSon A. 2013. Ataluren as an agent for therapeutic nonsense suppression. Annu Rev Med 64: 407-425.
Politano L, Nigro G, Nigro V, Piluso G, Papparella S, Paciello O AND COMi LI. 2003. Gentamicin administration in Duchenne patients with premature stop codon. Preliminary results. Acta Myol 22: 15-21.

POTTER M ET AL. 2014. A simplified purification protocol for recombinant adeno-associated virus vectors. Mol Ther Methods Clin Dev 1: 14034.

RAHMAN SH, MAEDER ML, Joung JK AND CATHOMEN T. 2011. Zinc-finger nucleases for somatic gene therapy: the next frontier. Hum Gene Ther 22: 925-933.

Rowe S, Sermet-Gaudelus I, Konstan M, Kerem E, Wilschanski M, Deboeck K, ACCURSo F, Miller NL, ELFRING GL AND BARTH J. 2012. Results of the phase 3 study of Ataluren in nonsense mutation cystic fibrosis (NMCF). Ped Pulm 67: 882-890.

RYAN NJ. 2014. Ataluren: first global approval. Drugs 74: $1709-1714$

SÁNCHEZ-Alcudia R, PÉREZ B, UGARTE M AND DESVIAT LR. 2012. Feasibility of nonsense mutation readthrough as a novel therapeutical approach in propionic acidemia. Hum Mutat 33: 973-980.

SARGENT RG, KIM S AND GRUENERT DC. 2011. Oligo/ polynucleotide-based gene modification: strategies and therapeutic potential. Oligonucleotides 21: 55-75.

SCAFFIDI P AND Misteli T. 2005. Reversal of the cellular phenotype in the premature aging disease HutchinsonGilford progeria syndrome. Nat Med 11: 440-445.

SERMET-GAUDELUS I ET AL. 2007. In vitro prediction of stopcodon suppression by intravenous gentamicin in patients with cystic fibrosis: a pilot study. BMC Med 5: 5.

SERMET-GAUDELUS I ET AL. 2010. Ataluren (PTC124) induces cystic fibrosis transmembrane conductance regulator protein expression and activity in children with nonsense mutation cystic fibrosis. Am J Respir Crit Care Med 182: 1262-1272.

SILVA AL AND ROMÃo L. 2009. The mammalian nonsensemediated mRNA decay pathway: to decay or not to decay! Which players make the decision? FEBS Lett 583: 499505 .

SMITH BK ET AL. 2013. Phase I/II trial of adeno-associated virus-mediated alpha-glucosidase gene therapy to the diaphragm for chronic respiratory failure in Pompe disease: initial safety and ventilatory outcomes. Hum Gene Ther 24: 630-640.

SPITALI P AND AARTSMA-Rus A. 2012. Splice modulating therapies for human disease. Cell 148: 1085-1088.

Suwanmanee T, Sierakowska H, Lacerra G, SVAsti S, Kirby S, Walsh CE, Fucharoen S and Kole R. 2002. Restoration of human beta-globin gene expression in murine and human IVS2-654 thalassemic erythroid cells by free uptake of antisense oligonucleotides. Mol Pharmacol 62: 545-553.

TAYLOR JK, ZHANG QQ, WyATT JR AND DEAN NM. 1999. Induction of endogenous $\mathrm{Bcl}-\mathrm{xS}$ through the control of 
Bcl-x pre-mRNA splicing by antisense oligonucleotides. Nat Biotechnol 17: 1097-1100.

Urnov FD, Miller JC, LeE YL, Beausejour CM, Rock JM, Augustus S, JAmieson AC, Porteus MH, Gregory PD AND HolmES MC. 2005. Highly efficient endogenous human gene correction using designed zinc-finger nucleases. Nature 435: 646-651.

VAN DEUTEKOM JC ET AL. 2007. Local dystrophin restoration with antisense oligonucleotide PRO051. N Engl J Med 357: 2677-2686.

VeCSLER M, ZeEV BB, Nudelman I, ANIKSTER Y, Simon AJ, Amariglio N, Rechavi G, BAASOV T AND GAK E. 2011. Ex vivo treatment with a novel synthetic aminoglycoside NB54 in primary fibroblasts from Rett syndrome patients suppresses MECP2 nonsense mutations. PLoS One 6: e20733.

WANG GS AND COOPER TA. 2007. Splicing in disease: disruption of the splicing code and the decoding machinery. Nat Rev Genet 8: 749-761.

Welch EM ET AL. 2007. PTC124 targets genetic disorders caused by nonsense mutations. Nature 447: 87-91.

WHO - World Health Organization. 2014. Ageing. Available in: http:/www.who.int/topics/ageing/en/. Accessed at November 23, 2014.
WILSCHANSKI M ET AL. 2003. Gentamicin-induced correction of CFTR function in patients with cystic fibrosis and CFTR stop mutations. N Engl J Med 349: 1433-1441.

Wilton SD AND Fletcher S. 2011. RNA splicing manipulation: strategies to modify gene expression for a variety of therapeutic outcomes. Curr Gene Ther 11: 259275.

WONG GKY AND CHIU AT. 2010. Gene therapy, gene targeting and induced pluripotent stem cells: applications in monogenic disease treatment. Biotechnol Adv 28: 715724.

WoOD MJA, GAIT MJ AND YIN H. 2010. RNA-targeted splicecorrection therapy for neuromuscular disease. Brain 133: 957-972.

Ye L, Chang JC, Lin C, Sun X, Yu J AND Kan YW. 2009. Induced pluripotent stem cells offer new approach to therapy in thalassemia and sickle cell anemia and option in prenatal diagnosis in genetic diseases. Proc Natl Acad Sci USA 106: 9826-9830.

ZHONG L, JAYANDHARAN GR, ASLANIDI GV, ZOLOTUKHIN S, Herzog RW and Srivastava A. 2012. Development of Novel Recombinant AAV Vectors and Strategies for the Potential Gene Therapy of Hemophilia. J Genet Syndr Gene Ther Suppl 1. 